\title{
New and rare myxomycetes of Ukraine. 1. East Forest-Steppe
}

\author{
DMITRY V. LEONTYEV, UNO ELIASSON, ANASTASIA V. KOCHERGINA and \\ IRINA I. MOROZOVA
}

LEONTYEV, D.V., ELIASSON, U., KOCHERGINA, A.V. \& MOROZOVA, I.I. 2009 : New and rare myxomycetes of Ukraine. 1. East Forest-Steppe. - Karstenia 49: 61-67. Helsinki. ISSN 0453-3402.

During the 2006-2008 summer-autumn seasons, the myxomycete biodiversity was investigated in Gomolsha Forests National Nature Park and neighbouring territories of the East Forest-Steppe area of Ukraine. Several earlier collections (2002-2004) were also reexamined. Four species found appeared to be new for Ukraine, six others were estimated as rare for the country. Descriptions, microphotographs, localities and information on substrata are presented for these species.

Key words: Myxomycota, biodiversity, Ukraine, East Forest-Steppe

Dmitry V. Leontyev, Department of Botany, National Pharmaceutical University, Kharkiv, Ukraine

Uno Eliasson, Department of Plant and Environmental Sciences, University of Gothenburg, Sweden

A.V. Kochergina, Volgograd State Medical University, Russia

I. I. Morozova, V. N. Karasin National University of Kharkiv, Ukraine

\section{Introduction}

Ukraine is situated in the eastern part of the European continent, occupying an area of 603-700 sq. $\mathrm{km}$. The territory of Ukraine includes several different biogeographic zones, such as deciduous forest, forest-steppe, grass steppe, maquis communities etc. The climate changes from moderate in the north to arid subtropical in the south. The topography of Ukraine is rather various: there are extensive plains, some flat heights and two mountain ridges, East Carpathian (up to $2061 \mathrm{~m}$ above sea-level) and Crimean (up to $1545 \mathrm{~m}$ ). The variation in climate and topography gives rise to a wide variety of ecosystems, among which there are alpine meadows, mountain fir-woods, plain oak forests, flood-land pine forests, water-meadows, peatbogs, saline lands etc. This variation in nature habitats provides a high diversity of many living organisms, including Myxomycetes - the fungi-like protists, close- ly related to lobose amoeboids but able to form macroscopic fruiting bodies.

Investigations of myxomycetes have been carried out in Ukraine rather intensively. During the past ten years the list of species recorded has increased by 86 species and now amounts to 232 species (Novozhilov 1993, Romanenko 2006, Leontyev 2006 a, Arnould et al. 2008). Detailed records on myxomycete biota have been provided for the Crimean Nature Reserve (Romanenko 2006) and the Gomolsha Forests National Natural Park (Leontyev 2006 a). Some data based on collections of single expeditions have also been published for Cape Martyan, Carpatskiy, Chornomorskiy, Dneprovsko-Orilskiy, Kanivskiy and Yaltinskiy Nature Reserves, and also for Desnyansko-Starogutskiy, Golosievskiy, Podilsky Tovtry, Svyaty Hory and Shatzkiy National Parks (Dudka 2000, Dudka Krivomaz 1996, 
2006, Dudka et al. 1999, Krivomaz 2001, 2003, Leontyev 2003, 2005, Leontyev et al. 2008). As a result of these investigations basic data on myxomycete diversity of all the main nature protected areas of the country have been obtained. Still, the species composition in most of the territories is insufficiently known. Therefore, further investigations on the myxomycete biodiversity in most of the natural reserves and national parks of Ukraine are needed.

The East Forest Steppe or so called Kharkiv Forest Steppe region is situated in the north-eastern part of Ukraine, on the southern spurs of the Central Russian Upland (Fig. 1). It is covered mostly by broad-leaf forests dominated by Quercus robur L., Acer platanoides L., Tilia cordata L., Fraxinus excelsior L., Ulmus scabra L., Populus tremula L., coniferous forests of Pinus silvestris L., and steppe-meadow and water-meadow communities. The most important nature protected territory of the region is the Gomolsha Forests National Nature Park (GFNNP), 40000 hectares, an area exhibiting all the abovementioned types of vegetation. Another important protected territory is the Sokolniky-Pomerky Regional Reserve (SPRR), situated $40 \mathrm{~km}$ north from GFNNP and covered predominately with Quercus-Acer-Tilia forest.

The Kharkiv Forest Steppe region is comparatively well studied regarding myxomycete diversity. There are 143 species of myxomycetes known from here, including rare species like $A r$ cyria helvetica (Meyl.) H. Neubert, Nowotny \& K. Baumann, Diderma montanum (Meyl.) Meyl., Echinostelium coelocephalum T.E. Broox \& H.W. Keller, Paradiacheopsis rigida (Brândză) Nann.-Bremek. in Alexop. \& G.W. Martin, Stemonitopsis peritricha (Nann.-Bremek.) Nann.Bremek. (Leontyev 2006 b). During the last collecting seasons we found in the park and neighbouring territories some species never recorded from there before. Some of them appeared to be quite rare or even new to Ukraine.

\section{Material and methods}

The material was collected during the 2006-2008 summer-autumn seasons under field conditions (fc) and in moist chamber cultures (mc). Collected specimens were placed in the National Scientific Herbarium of V.N. Karasin National University of Kharkov (CWU), mycology section. Spores were studied in temporary water preparations. Studies of the capillitium were carried out using permanent lactophenol preparations (for Stemonitales) and permanent glycerin preparations (for Physarales and Trichiales). Nomenclature is given according to J.C. Hernández-Crespo and C. Lado (www.eumycetozoa. com). Distribution of species is given according to the database of Eumycetozoan Research Project (http//:slimemolds.uark.edu). Microphotographs were taken using the digital photo camera Canon Power Shot A510.

\section{Remarks on noteworthy records}

As a result of our research four species of myxomycetes were found new for Ukraine (*). Another six species were found to be rare in the country. Here we apply the term "rare" to species that were not found in Ukraine more than three times before. Since the biota of myxomycetes in Ukraine could hardly be called little-studied, such a kind of distribution affords the ground for asserting that the species is indeed rare.

A list of myxomycetes new or rare for Ukraine is given below. Descriptions, ecological data, and, in some cases, comments on morphological and other features are given for each species.

Calomyxa metallica (Berk.) Nieuwl. - Fig. 2.4 On the bark of a living Quercus robur tree, RPSP, upland oak forest, mc, 09.2008.

Fructification with only spherical sporocarps, sessile on a small base, 0.1-0.2 mm diam., iridescent with bluish and lilac tint but without the yellow colour typical of the species. Peridium thin, translucent, smooth. Dehiscence irregular. Capillitial threads 0.8-2.2 $\mu \mathrm{m}$ diam., long, sinuous, with few connections to the peridium. Threads covered with small, spirally arranged spinules or wartlets. Spores beige in mass, light rosy-greyish in transmitted light, 10-11 $\mu \mathrm{m}$ diam., thickwalled, somewhat irregular in shape, covered with small spines or warts. Plasmodium not seen.

This type of macromorphology of the species is known only from a few published illustrations (Emoto 1977, Mitchell 2002) and may be caused by the moist chamber conditions.

The species has been found twice before in Ukraine, in the Carpathians (Krzeminiewska 1934) and in the Yalta Mountain-Forest Reserve in the south of the Crimea peninsula (Romanenko 2006). Our record is the first record for the plain part of Ukraine. 
Comatricha elegans (Racib.) G. Lister - Fig. 2.1

On dead wood of Populus tremula L., GFNNP, Is'kov steep bank, flooded Quercus-Ulmus forest, fc, 07.2006.

Sporocarps stalked, spherical, purple-brown, $0.3-0.5 \mathrm{~mm}$ in diam. Peridium fugacious, in some fruitbodies leaving a small vestige (Fig. 1) at the base of the sporotheca. Stalk $1.0-1.5 \mathrm{~mm}$ long, thin, awl-shaped all the way to the base. Columella repeatedly dichotomously branched at the base of sporangia, turning into the system of capillitium. Capillitial threads thin, winding, anastomosing to form an internal network with some free endings at the periphery. Spores 8-10 $\mu \mathrm{m}$, with small warts, red-brown in mass and hazel-brown in transmitted light. Plasmodium not observed.

The species has previously been found in Ukraine only in the Yalta Mountain-Forest Reserve (Romanenko 2006). Our record is the first for the continental part of the country.

Comatricha ellae Härk. - Fig. 2.2

On dead wood of Pinus sylvestris L., GFNNP, Zadonetskiy woodland, sq. 84 and 95, Pinus forest, fc, 07.2006.

Sporocarps stalked, spherical, dark-brown, $0.3-0.4 \mathrm{~mm}$ in diam. Peridium fugacious. Stalk about $1 \mathrm{~mm}$ long, awl-shaped, black, its base red-brown in transmitted light. Columella an extension of the stalk; in the middle part of the sporotheca forked into 2-4 branches usually directed at right angles to the columella. Capillitium arising from all parts of the columella, branched and anastomosing to form a gentle surface net with accurate meshes and very few free ends. Spores 7-9 $\mu \mathrm{m}$, with small warts, rusty-brown in mass and violet-brown in transmitted light. Plasmodium not observed.

Comatricha ellae is a morphologically homogeneous species, which seems to be related to the polymorphic complex of $C$. nigra (Pers. ex J.F.Gmel.) J.Schröt. In view of the first author of this paper, relations between $C$. nigra and $C$. ellae well illustrate the empiric Zipf's Law, biological interpretation of which shows that widespread polymorphic species are often accompanied by the 'loop' of sister taxa, that show the extreme state of 'central' species features. Such regularity could be based on the principle of myxomycete population biology shown by
M. Schnittler and J.Tesmer: the variable "sexual core" of the population continuously produces new asexual strains, which show a more stable morphology (Schnittler \& Tesmer 2008).

Comatricha ellae has been found twice before in Ukraine, both in Mountain Crimea: in Crimea Nature Reserve (Krivomaz 1998) and the Yalta Mountain-Forest Reserve (Romanenko 2006). Our record is the first for the continental part of the country

Diderma floriforme (Bull.) Pers. - Figs. 2.52.6

On the bark of fallen trunk of Quercus robur L., GFNNP, Korobov woodland, sq.44, oak-hazel forest, fc, 07.2006.

Sporocarps stalked, gregarious, subglobose, $0.7-1 \mathrm{~mm}$ in diam., pearl-grey to greyish-beige, shining. Hypothallus inconspicuous, membranous, brown. Peridium double; an outer layer cartilaginous, calcareous, ochraceous, inner surface of the layer pale brown. An internal layer of peridium membranous, connected with the outer one. Peridium dehiscing with petal-shaped lobules. Stalk about $1.0 \mathrm{~mm}$ long, calcareous, cylindrical, wrinkled, brown. Columella large, clavate, reddish-ochraceous, with rough surface. Capillitium consisting of poorly branched thin filaments with small rounded swellings. Spores $10-11 \mu \mathrm{m}$ in diam., warty, with a 'pale area' on one side, dark purple-brown in mass, violetbrown in transmitted light. Plasmodium whitish.

This species was recorded on the territory of Ukraine only once before, in 1925, in Right-Bank Woodlands (Zelle 1925). It is a widespread species (Europe, Asia, North America), although everywhere quite rare. Ing (1999) has commented on the reduction of natural habitats of Diderma floriforme in Great Britain, where the last findings of this species in some regions date back to the 18 th century.

*Didymium applanatum Nann.-Bremek. - Fig. 2.7

On moss, GFNNP, Korobov woodland, sq. 44, Quercus-Corylus forest, fc, 07.2006.

Sporocarps in small groups, stalked, greyishwhite. Sporotheca discoid, $0.1-0.2 \mathrm{~mm}$ high and $1 \mathrm{~mm}$ in diam., usually with a small depression above. Stalk extending into a whitish umbilicus at bottom of the sporotheca. Hypothallus prostrate, whitish due to deposits of calcium. Stalk 
about $1 \mathrm{~mm}$ long, yellowish white, grooved, noticeably broadening towards base. Peridium membranous, semi-translucent, covered on the outside with white star-shaped calcium crystals larger than the spores. Columella absent. Capillitium consisting of hyaline, poorly branched threads, arising from the base of the peridium and radiating towards the periphery. Spores 8-10 $\mu \mathrm{m}$ in diam., covered with clustered warts, umber-brown in mass, pale greyish-violet in transmitted light.

Didymium applanatum is similar to D. clavus (Alb. et Schwein.) Rabenh., except for the white colour of stalk and umbilicus caused by the presence of calcium.

Our record of the species is the first for the territory of Ukraine. It appears that this species has not been found on mosses before (Ing 1999).

Didymium bahiense Gottsb. - Fig. 2.9

On leaf litter of Quercus robur L., GFNNP, Korobov woodland, Quercus-Acer-Tilia forest, fc, 07.2003; on germs of Hordeum vulgare L., Kharkov area, Zolochevskiy district, mc, 10.2004; on the bark of Armeniaca vulgaris Lam., Zolochevskiy district, mc, 05.2004.

Sporocarps single, stalked, flat-oval, greyishwhite, $0.7-1.9 \mathrm{~mm}$ tall, $0.25-0.6 \mathrm{~mm}$ in diameter, white, almost spherical. Apex of stalk submerged into sporangia, forming a small umbilicus (hardly visible from the outside). Hypothallus small, almost black. Stalk long, drooping, without calcium, ochraceous in the upper part, dark brown at base from included particles. Peridium thin, yellowish in transmitted light, covered on the outside with star-shaped lime crystals, which are the same size as the spores. At the bottom of sporangia, the rounded limy pseudocolumella is present. Capillitial threads abundant, dichotomous, laxly anastomosing, brown with pale ends and small dark swellings. Spores $10-11 \mu \mathrm{m}$ in diam., cluster-warted, umber-brown in mass, lilac-grey in transmitted light. Plasmodium not seen.

Didymium bahiense belongs to the 'Didymium iridis-complex' (Clark \& Mires 1999), and the fact that this species had not been recorded for Ukraine before may be due to confusion with other species within this complex. However, characters like the drooping limeless stalk and the large pseudocolumella clearly distinguish $D$. bahiense from other species of the complex.

The species was found in Ukraine only once, in Desniansko-Starogutskiy National Nature Park in the East Forest region (Dudka \& Krivomaz 2006). Our record is new for the East Forest-Steppe region.

\section{*Didymium flexuosum Yamash. - Fig. 2.8}

Leaf litter of Quercus robur L., GFNNP, Quercus-Acer-Tilia forest, mc, 07.2005.

Plasmodiocarps smoky-grey, branched and anastomosing to form an intricate net, with occasional simple plasmodiocarps $0.2-0.4 \mathrm{~mm}$ wide. Hypothallus membranous, inconspicuous. Peridium thin, membranous, with slight iridescence, sparsely to densely powdered with white calcium crystals. Columella formed by the thickened base of the plasmodiocarp, extending longitudinally nearly the full length of the fruitbody. Capillitium consisting of dense, brownish threads with few anastomoses. Spores 11-13 $\mu \mathrm{m}$ in diam., spiny, black in mass, pale brown in transmitted light. Numerous vesicular bodies present in the spore mass, paler than spores and larger and irregular in shape. Plasmodium dirty-white.

Our record of the species is the first for the territory of Ukraine. The specimen had earlier been misidentified as Didymium dubium Rostaf. (Leontyev 2006 b).

\section{*Fuligo rufa Pers. - Fig. 2.10}

Bark and wood of fallen trunks and stumps of Pinus sylvestris L., GFNNP, Zadonetskiy woodland, sq.101 and 104, pine forest, 06-07.2006.

Aethalium single, pulvinate, $2-10 \mathrm{~cm}$ in diam., light reddish-brown. Hypothallus rough, fibrous, yellowish. Cortex double-layered, the outer layer 2-3 mm thick, encrusted with calcium, light reddish-brown, fragile, easily loosening. The inner layer powdery, greyish-white, attached to the rest of the aethalium. Innermost peridium membranous, colorless. Capillitium consisting of the translucent tubes of the merged individual sporocarps, forming an internal net. Lime nodes small, spindle-shaped. Spores 6-7 $\mu \mathrm{m}$ in diam, spiny, almost black in mass, pale lilac-grey in transmitted light. Plasmodium rosy-cream.

This species is rather abundant in the explored territory. The absence of data on the distribution of Fuligo rufa in Ukraine may be explained by the fact that this species was considered by many authors to be a variety of F. septica (L.) 
F.H.Wigg. However, such characters as a double cortex, the specific colour of the aethalium and the size of spores distinguish $F$. rufa from other species of the genus (Nannenga-Bremekamp 1992, Neubert et al. 1995).

\section{Lindbladia tubulina Fr. - Fig. 2.11}

Wood of fallen trunks and stumps of Pinus sylvestris L., GFNNP, Zadonetskiy woodland, pine forest, fc, 06-07.2004, 06-07.2005.

Pseudoaethalia large, prostrate, varying in colour from greenish-brown to olive-green, 30-40 $\mathrm{mm}$ long and 25-30 mm wide. Pseudoaethalium formed by the hemispheric or irregular apexes of individual sporocarps, which are tubule-like, sinuous. Hypothallus inconspicuous, spongy. Peridium membranous, smooth or slightly wrinkled. Spores 5.5-6.5 $\mu \mathrm{m}$ in diam., minutely warted, olive-green in mass, dirty-yellowish in transmitted light. Plasmodium watery, later becoming deeply black.
All samples we have found represent the same morphotype, which we call the 'tubiferoid' type: fruiting bodies are large pseudoaethalia with cylindrical individual sporocarps and peridium lacking a network. The species may also have another morphotype - 'cribrarioid', characterized by grouped spherical sporocarps and a reticulated peridium. We have collected samples of the 'cribrarioid' type in the spruce forests of the Pskov area of Russia (Fig. 2.12). This morphotype has so far not been recorded from the territory of Ukraine. There is an unresolved question as to whether the two morphotypes are due to different environmental conditions or are genetically distinct.

The species was recorded from Ukraine only twice before, both times in the Carpathians and quite long ago (Krupa 1889, Krzemieniewska 1934). Our record is the first record for the plain part of the country.

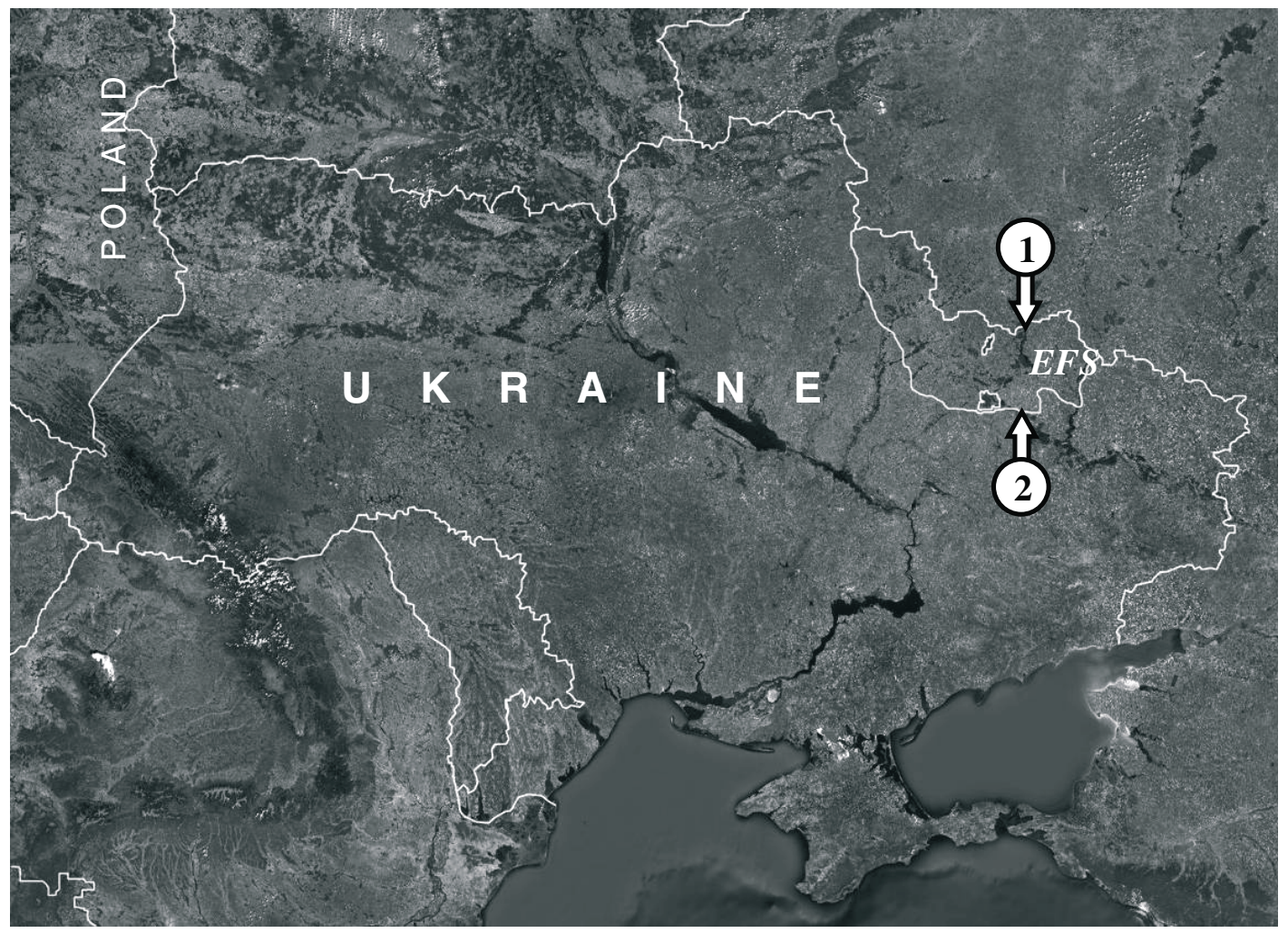

Fig. 1. Study area. - 1: Sokolniky-Pomerky Regional Reserve; 2: Gomolsha Forests National Nature Park; EFS: East Forest-Steppe region of Ukraine. 


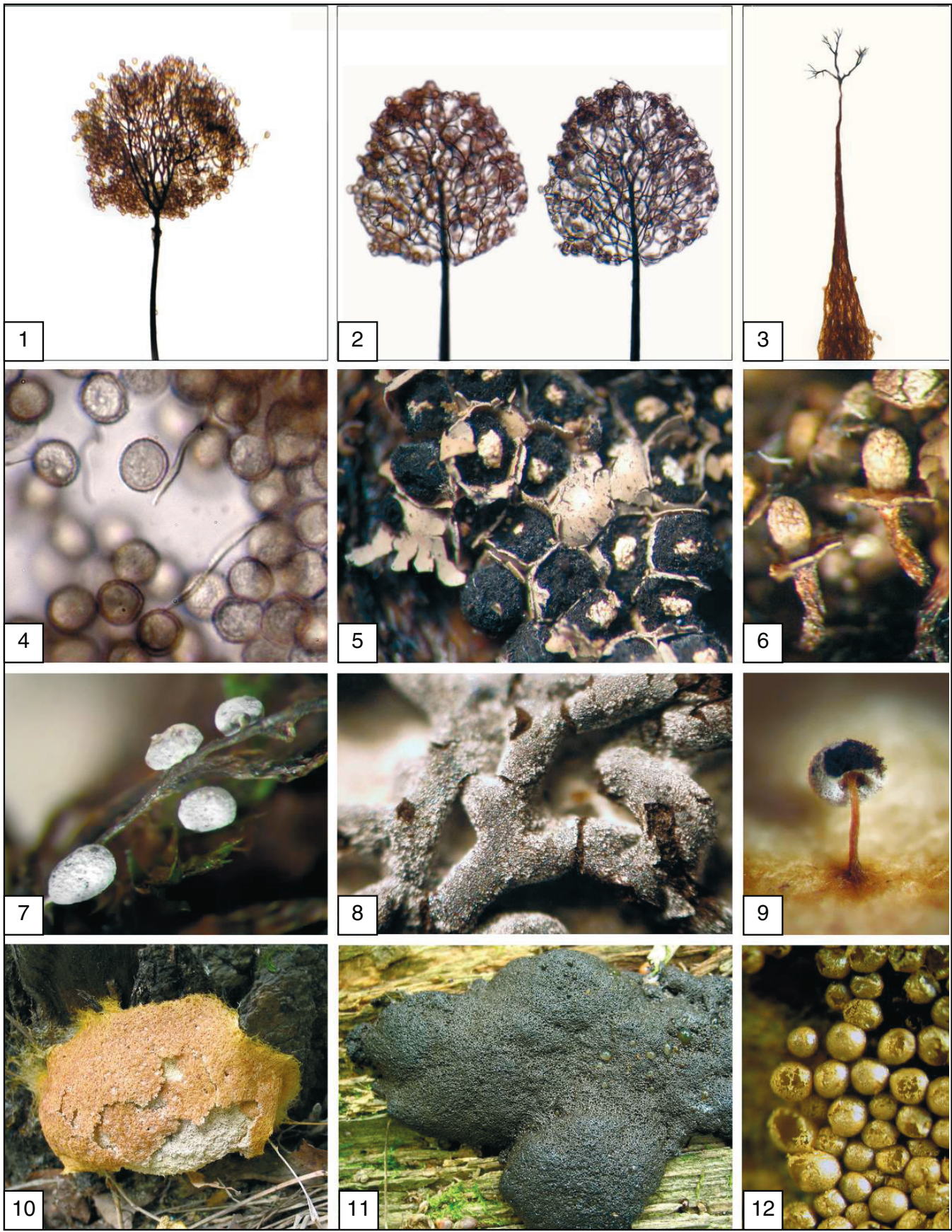

Fig. 2. Species collected in the East Forest-Steppe of Ukraine. - 1. Comatricha elegans (Racib.) G. Lister, sporangium. $\times 300 ; 2$. Comatricha ellae Härk.; sporangium, $\times 300$. 3. Paradiacheopsis acanthodes (Alexop.) Nann.-Bremek., sporangium, $\times$ 300. 4. Calomyxa metallica (Berk.) Nieuwl., capillitium and spores, $\times 600.5$. Diderma floriforme (Bull.) Pers., sporangia from above, $\times$ 15. 6. D. floriforme, sporangia from the side: columella seen, $\times 15$. 7. Didymium applanatum Nann.-Bremek., sporangia, $\times$ 15. 8. Didymium flexuosum Yamash., plasmodiocarp, $\times$ 30. 9. Didymium bahiense Gottsb., sporangium, $\times 30$. 10. Fuligo rufa Pers., aethalium, $\times 0.5$. 11. Lindbladia tubulina Fr., pseudoaethalium of 'tubiferoid' form, $\times$ 0.5. 12. L. tubulina, sporangia of 'cribrarioid' form, $\times 15$. 


\section{*Paradiacheopsis acanthodes (Alexop.) Nann.- Bremek. - Fig. 2.3}

Bark of Quercus robur L., GFNNP, Korobov woodland, oak-hazel forest, mc, 07.2003.

Sporocarps solitary, spherical, brown, $0.2 \mathrm{~mm}$ in diam. Stalk $0.5 \mathrm{~mm}$ long, awl-shaped, reddishbrown in transmitted light, with a broad, fibrous base. Peridium disappearing in mature fruitbodies. Stalk continuing into a columella reaching the center of the sporotheca. Capillitium consisting of three slender, black branches, arising from the tip of the columella and forking 2-3 times, with pointed tips and no anastomoses. Spores 13 $\mu \mathrm{m}$ in diam., spiny, dark-brown in mass, greyish in transmitted light. Plasmodium not seen.

Our record of the species is the first for the territory of Ukraine. The species is generally rare and strongly resembles Paradiacheopsis fimbriata (G. Lister et Cran) Hertel ex Nann.-Bremek., but the features of the capillitium and spores distinguish it from other species of the genus.

\section{References}

Arnould, C., Fefelov, K., Fenouil, T., Fiore-Donno, A.M., Haugli, K., Hayova, V.P., Kryvomaz, T.I., Lavoise, C., Leontyev, D.V., McHugh, R., Meyer, M., Michaud, A., Rouvière, F., Rouvière, M., Seraoui, H. \& Zemlyanskaya, I.V. 2008: Nivicolous myxomycetes in Ukrainian Carpathians. - Abstracts of $6^{\text {th }}$ International Congress on the Systematics and Ecology of Myxomycetes, Yalta, 10 October 2008: 80.

Clark, J. \& Mires, A. 1999: Biosystematics of Didymium: the non-calcareous, long-stalked species. - Mycotaxon. 71: 369-382.

Dudka, I.A. 2000: New nivicolous myxomycete records from Crimea for Ukraine. - Ukr. Bot. J. 57: 57-61 (in Ukrainian).

Dudka, I.A. \& Krivomaz, T.I. 1996: New myxomycete records from the Ukrainian Carpathians. - Ukr. Bot. J. 53: 710-716 (in Ukrainian).

Dudka, I.A. \& Krivomaz, T.,I. 2006: Myxomycetes of the national natural reserves of the Ukranian Polyssia. - Mikol. Fitopatol. 40: 25-32 (in Russian).

Dudka, I.A., Kuzub, V.V.\& Romanenko, E.A. 1999: Myxomycetes of the Yalta mountain-forest reserve. - Mikol. Fitopatol. 33: 307-315 (in Russian).

Emoto, Y. 1977: The myxomycetes of Japan. - Tokyo: Sangyo Tosho. 263 p.

Ing, B. 1999: The myxomycetes of Britain and Ireland. An identification handbook. - Slough: The Richmond Publishing Co. Ltd. 375 pp.

Krivomaz, T.I. 2001: New myxomycete records for the territory of the Dneprovsko-Orelskiy Reserve. - In: The actual problems on botany and ecology: 16. ZnobNovgorodskiy; Nizhin (in Russian).
Krivomaz, T.I. 2003: Myxomycetes of the Rivnenskiy Natural Reserve. - Ukr. Bot. J. 60: 633-642 (in Russian).

Krupa, J. 1889: Zapiski mycologiczne z okolic Lwowa i Karpat Stryjskich [Mycological notes from environs of Lviv and Stryjski Carpathian Mts]. - Sprav. Kom. Fizyogr. 23: 141-169. (in Polish)

Krzeminiewska, H. 1934: Sluzowce Karpat Wschodnich. - Kosmos. 59: 207-223 (in Polish).

Leontyev, D.V. 2003: New myxomycete records from the Kanevskiy Natural Reserve. - In: The actual problems on biology in researches of young scientists from the Kharkov University. Kharkov: 17-19 (in Russian).

Leontyev, D.V. 2005: New myxomycete records from the Cape Martyan and Yalta Mountain-Forest Reserves. - In: Reserves of Crimea: biodiversity on the priority territories: 221-224. Simferopol. (in Russian).

Leontyev, D.V. 2006a: Myxomycete species structure (Myxomycota) of the Gomolsha Forests National Natural Reserve (Ukraine). - Mikol. Fitopatol. 40: 101-107 (in Russian).

Leontyev, D.V. 2006b: Myxomycete species new for Ukraine. - Mikol. Fitopatol. 40: 218-230.

Leontyev, D.V., Dudka, I.O. \& Kryvomaz, T.I. 2008: Addition to the myxomycetes biota of the Podylsky Tovtry National Nature Park. - Third International Conference "The Biology from molecule to biosphere", Kharkiv, 18-21 November 2008: 416-417.

Mitchell, D.W. 2002: Myxomycetes 2002. Synoptic Key. - Identification database on CD.

Nannenga-Bremekamp N.E. 1992: A guide to temperate Myxomycota. -Bristol: Biopress Ltd. 410 pp.

Neubert H., Nowotny W., Baumann K. 1995: Die Myxomyceten Deutschlands und des angrenzenden Alpenraumes unter besonderer Berücksichtigung Österreichs 2. Physarales. - Gomaringen: Karlheinz Baumann Verlag. 365 pp.

Novozhilov, Y.K. 1993: Phylum Myxomycota. - In: The key for fungi of Russia 1. Nauka, St.-Petersburg. (in Russian),

Romanenko, K.O. 2006: Myxomycetes of the Crimean Nature Reserve: - PhD Thesis, M.G. Cholodniy's Institute of Botany. Kiev (in Ukrainian).

Schnittler, M. \& Tesmer, J. 2008: A habitat colonisation model for spore-dispersed organisms - does it work with eumycetozoans? - Abstracts of International Congress on the Systematics and Ecology of Myxomycetes: 62. Yalta.

Zelle, M.A. 1925: Data on flora of myxomycetes of Ukraine. - Bulletin of the Kiev Botanic Garden. 2: 31-39 (in Ukrainian). 